\title{
Ultrastructure of Mikrocytos mackini, the cause of Denman Island disease in oysters Crassostrea spp. and Ostrea spp. in British Columbia, Canada
}

\author{
P. M. Hine ${ }^{1, *}$, S. M. Bower ${ }^{2}$, G. R. Meyer ${ }^{2}$, N. Cochennec-Laureau ${ }^{1}$, F. C. J. Berthe ${ }^{1}$ \\ ${ }^{1}$ Laboratoire de Génétique et Pathologie, IFREMER, B.P. 133, Ronce-les-Bains, 17390 La Tremblade, France \\ ${ }^{2}$ Department of Fisheries and Oceans, Biological Sciences Branch, Pacific Biological Station, Nanaimo, British Columbia, \\ V9R 5K6 Canada
}

\begin{abstract}
An ultrastructural study was carried out on Mikrocytos mackini, the cause of Denman Island disease in Pacific oysters Crassostrea gigas in western Canada. Three forms were identified, quiescent cells (QC), vesicular cells (VC) and endosomal cells (EC). QC occurred in the vesicular connective tissue (VCT), haemocytes (hyalinocytes), adductor and heart myocytes, and extracellularly. They had a central round to ovoid nucleus, $<7$ cisternae of inactive nuclear membrane-bound Golgi, few vesicles and lysosome-like bodies. VC were rarely extracellular and usually occurred in adductor and heart myocytes, in close association with host cell mitochondria. The contents of the host cell mitochondria appeared to pass through a tubular extension into the cytoplasm of the parasite. Cytoplasmic vesicles resembled the tubular structure in appearance and size. EC occurred in the VCT, in haemocytes and extracellularly. They had a dilated nuclear membrane, sometimes containing a looped membranous structure that appeared to derive from the nucleus, and pass into the cytoplasm. A well-developed anastomosing endoplasmic reticulum connected the nuclear and plasma membranes, and endosomes were present in the cytoplasm. QC and EC cells were frequently observed tightly against, or between, the nuclear membranes of the host cell. Few organelles occurred in all forms of M. mackini, especially QC. The lack of organelles found in most eukaryotic cells, including mitochondria or their equivalents, may be due to obligate parasitism and the utilization of host cell organelles reducing the need for parasite organelles. Alternatively, perhaps $M$. mackini is a primitive eukaryote. Although phylogenetic affinities could not be determined, it is not a haplosporidian. A developmental cycle is proposed from these findings.
\end{abstract}

KEY WORDS: Mikrocytos mackini · Crassostrea gigas · Ultrastructure · Amitochondriate protozoan · Denman Island disease

Resale or republication not permitted without written consent of the publisher

\section{INTRODUCTION}

Denman Island disease, or mikrocytosis, is an OIE (Office International des Epizooties, the World Animal Health Organization) internationally notifiable disease affecting Pacific oysters Crassostrea gigas at various locations on the southern coast of British Columbia,

${ }^{*}$ Present address: Aquatic Animal Diseases, National Centre for Disease Investigation, MAF Operations, PO Box 40-742, Upper Hutt, New Zealand. E-mail: hinem@maf.govt.nz
Canada. It was first noticed in 1960, when 17 to $35 \%$ of oysters died in Henry Bay, Denman Island (Quayle 1961). From 1960 to 1994, prevalence of infection fluctuated from $11 \%$ (1967) to $48 \%$ (1988), in mid-March to mid-May (Hervio et al. 1996). The disease occurs following 3 to $4 \mathrm{mo}$ of $<10^{\circ} \mathrm{C}$ temperatures and does not occur at $>12^{\circ} \mathrm{C}$, but infections may persist for 3 mo at $15^{\circ} \mathrm{C}$ (Bower et al. 1994). Infected oysters may have green pustular abcess-like lesions in the tissues of the mantle and palps, and the adductor muscle may also be infected (Hervio et al. 1996). Histologically, focal 
intracellular infection of vesicular connective tissue cells and myocytes causes haemocyte infiltration and tissue necrosis (Bower et al. 1994). The disease may also occur in Ostrea edulis, Ostrea conchaphila, and Crassostrea virginica. However, temperatures above $15^{\circ} \mathrm{C}$ prevent the disease from developing in these oysters although infection may persist (Bower et al. 1997).

The aetiological agent is a small eukaryotic cell, called a 'microcell', and described as Mikrocytos mackini (Farley et al. 1988). There are 3 other microcell parasites of oysters: Bonamia ostreae and Bonamia sp. infecting Ostrea spp., and Mikrocytos roughleyi infecting Saccostrea glomerata (= S. commercialis). There have been several descriptions of the ultrastructure of Bonamia spp. (Pichot et al. 1979, Brehélin et al. 1982, Balouet et al. 1983, Hine 1991, 1992, Hine \& Wesney 1992, 1994a,b) showing them to be haplosporidians with typical haplosporosomes and mitochondria. The ultrastructure of $M$. roughleyi, like that of M. mackini, has not been reported. This study was undertaken to determine the ultrastructure and host:parasite relationships of M. mackini, and compare them with Bonamia spp.

\section{METHODS}

Between May 1987 and April 1992, tissues from infected Crassostrea gigas were fixed in $4 \%$ glutaraldehyde in Millonig's buffer and post-fixed for $1 \mathrm{~h}$ in $1 \%$ osmium tetroxide $\left(\mathrm{OsO}_{4}\right)$ in Millonig's buffer. In October 1995, infected tissues from C. gigas were also fixed in either (1) $2.5 \%$ glutaraldehyde in $0.1 \mathrm{M}$ phosphate buffer ( $\mathrm{pH} 7.0$ ) for $2 \mathrm{~h}$ at $\sim 4^{\circ} \mathrm{C}$, washed in $1.7 \%$ sucrose in $0.2 \mathrm{M}$ phosphate buffer for $2 \times 10 \mathrm{~min}$, postfixed in $1 \% \mathrm{OsO}_{4}$ in $0.13 \mathrm{M}$ phosphate buffer with $0.5 \%$ potassium ferricyanide and $0.15 \mathrm{M}$ sucrose for $2 \mathrm{~h}$ at 20 to $22^{\circ} \mathrm{C}$ in the dark, or (2) $2.5 \%$ glutaraldehyde and $1 \% \mathrm{OsO}_{4}$ in $0.1 \mathrm{M}$ cacodylate buffer for $1.25 \mathrm{~h}$ at room temperature in the dark, washed and post-fixed in $1 \% \mathrm{OsO}_{4}$ using the same buffer. In July 1999 tissues from C. virginica, and in September 1999 tissues from Ostrea edulis and C. virginica were fixed in $2.5 \%$ glutaraldehyde in Sorenson's buffer ( $\mathrm{pH} 7.2$ ) for 1 to $2 \mathrm{~h}$, washed $\times 2$ in buffer, and post-fixed for $1 \mathrm{~h}$ in $1 \% \mathrm{OsO}_{4}$ in Sorenson's buffer. Following post-fixation, dehydration and embedding in Epon, ultrathin sections were stained with lead citrate and uranyl acetate. This study is based on examination of 108 electron micrographs, 81 of the parasite at identifiable sites.

\section{RESULTS}

Three parasite stages were observed; a quiescent stage, a vesicular stage and an endosomal stage. No differences were observed in the morphology of Mikrocytos mackini from the 3 species of oysters. Dimensions of each stage and the size of organelles are given in Table 1. Tables 2, $3 \& 4$ summarize the ultrastructural features of each stage and indicate the distribution of each stage in relation to host tissue site and interaction with host cell organelles.

Table 1. Dimensions of Mikrocytos mackini and its organelles. aER: anastomosing endoplasmic reticulum; STBs: spherical thick-walled bodies

\begin{tabular}{|llll|}
\hline & Quiescent cells & Vesicular cells & Endosomal cells \\
\hline Number & 8 & 7 & 29 \\
Cell dimensions & $4.3-3.1 \times 3.7-2.9 \mu \mathrm{m}$ & $4.6-3.9 \times 3.5-2.4 \mu \mathrm{m}$ & $4.0-2.5 \times 3.7-1.6 \mu \mathrm{m}$ \\
Nucleus dimensions & $1.7-1.5 \times 1.6-1.3 \mu \mathrm{m}$ & $2.0-1.8 \times 1.6-1.4 \mathrm{~m}$ & $1.9-1.2 \times 1.8-1.1 \mu \mathrm{m}$ \\
Nucleolus ring-like & & & $250-241 \times 235-222$, outer \\
structure & & & $168 \times 130 \mathrm{~nm}$ \\
& & $1200-960 \times 1100-467 \mathrm{~nm}$ & $1100 \times 600 \mathrm{~nm}$ \\
Dilated nuclear vacuole & $533 \times 267 \mathrm{~nm}$ & & $423-260 \times 362-145 \mathrm{~nm}$, \\
Inclusion in nuclear & & & width $11-27 \mathrm{~nm}$ \\
membrane cisterna & & & $131-61 \times 78-51 \mathrm{~nm}$ \\
Width tubulovesicular Golgi & & & $283-98 \times 261-88 \mathrm{~nm}$, \\
aER & & & width membrane $18-25 \mathrm{~nm}$ \\
STBs & & $280-267 \times 207-147 \mathrm{~nm}$ & $162-137 \times 162-122 \mathrm{~nm}$ \\
& & & $280-150 \times 216-131 \mathrm{~nm}$, \\
Lysosome-like bodies & $170 \times 165 \mathrm{~nm}$ & & wall width $16 \mathrm{~nm}$ \\
Thick-walled endosomes & $267-230 \times 227-213 \mathrm{~nm}$ & $215-154 \times 278-142 \mathrm{~nm}$ \\
Large vesicles & $347-133 \times 293-133 \mathrm{~nm}$ & & $93-59 \times 81-55 \mathrm{~nm}$ \\
Small coated vesicles & $74-50 \mathrm{~nm}$ & & $77-64 \times 77-64 \mathrm{~nm}$ \\
Small uncoated vesicles & $20-50 \mathrm{~nm}$ & & \\
\hline
\end{tabular}


Table 2. Quiescent cell (QC); interaction with host cells and ultrastructural features. n: number examined; VCT: vesicular connective tissues; none: features that distinguish $\mathrm{QC}$ from endosomal cells (EC); aER: anastomosing endoplasmic reticulum; STBs: spherical thick-walled bodies

\begin{tabular}{|c|c|c|c|c|}
\hline & $\begin{array}{l}\mathrm{VCT}(\%) \\
(\mathrm{n}=6)\end{array}$ & $\begin{array}{l}\text { Haemocytes }(\%) \\
(\mathrm{n}=4)\end{array}$ & $\begin{array}{c}\text { Myocytes (\%) } \\
(\mathrm{n}=3)\end{array}$ & $\begin{array}{l}\text { Extracellular }(\%) \\
(\mathrm{n}=10)\end{array}$ \\
\hline \multicolumn{5}{|l|}{ Host cells } \\
\hline Inside host cell nuclear membrane & $1(17)$ & $4(100)$ & $1(33)$ & \\
\hline Apposition host cell mitochondria & $1(17)$ & $2(50)$ & $1(33)$ & $1(10)$ \\
\hline \multicolumn{5}{|l|}{ Parasite } \\
\hline Normal nuclear membrane & $5(83)$ & $4(100)$ & $3(100)$ & $10(100)$ \\
\hline Dilated nuclear membrane & $1(17)$ & & & \\
\hline \multicolumn{5}{|l|}{ Inclusion in nuclear membrane cisterna } \\
\hline Membrane-bound Golgi & $4(67)$ & $2(50)$ & & $3(30)$ \\
\hline \multicolumn{5}{|l|}{ Nuclear vacuole } \\
\hline aER & None & None & None & None \\
\hline Granular material & & & & $1(10)$ \\
\hline STBs & None & None & None & None \\
\hline Lysosome-like bodies & $2(33)$ & $1(20)$ & & $2(20)$ \\
\hline Thick-walled endosomes & None & None & None & None \\
\hline Large vesicles & $5(83)$ & $2(50)$ & $1(33)$ & $3(30)$ \\
\hline Small coated vesicles & $4(50)$ & $3(75)$ & $2(67)$ & $4(40)$ \\
\hline Small uncoated vesicles & $2(33)$ & $2(75)$ & & $1(10)$ \\
\hline
\end{tabular}

\section{Quiescent cells}

Quiescent cells (QC) occurred in vesicular connective tissue (VCT), haemocytes, at the edge of (extracellular) or in the adductor and heart myocytes (Fig. 1), and extracellularly, (Tables 1 \& 2). QC had a single central

Table 3. Vesicular cells (VC); interaction with host cells and ultrastructural features. n: number examined; none: features that distinguish $\mathrm{VC}$ from quiescent cells (QC) and endosomal cells (EC); aER: anastomosing endoplasmic reticulum; STBs: spherical thick-walled bodies

\begin{tabular}{|c|c|c|}
\hline & $\begin{array}{l}\text { Myocytes (\%) } \\
\quad(\mathrm{n}=9)\end{array}$ & $\begin{array}{l}\text { Extracellular }(\%) \\
(\mathrm{n}=4)\end{array}$ \\
\hline \multicolumn{3}{|l|}{ Host cells } \\
\hline $\begin{array}{l}\text { Inside host cell nuclear } \\
\text { membrane }\end{array}$ & & $1(25)$ \\
\hline $\begin{array}{l}\text { Apposition host cell } \\
\text { mitochondria }\end{array}$ & $7(78)$ & $1(25)$ \\
\hline \multicolumn{3}{|l|}{ Parasite } \\
\hline Normal nuclear membrane & $6(67)$ & $4(100)$ \\
\hline Dilated nuclear membrane & $3(33)$ & \\
\hline $\begin{array}{l}\text { Inclusion in nuclear } \\
\text { membrane cisterna }\end{array}$ & $2(22)$ & \\
\hline Membrane-bound Golgi & None & None \\
\hline Nuclear vacuole & $2(22)$ & $2(50)$ \\
\hline aER & $2(22)$ & \\
\hline Granular material & $1(11)$ & \\
\hline STBs & None & None \\
\hline Lysosome-like bodies & $1(11)$ & $1(25)$ \\
\hline Thick-walled endosomes & $2(22)$ & $1(25)$ \\
\hline Large vesicles & $3(33)$ & $1(25)$ \\
\hline Small coated vesicles & $9(100)$ & $4(100)$ \\
\hline Small uncoated vesicles & $7(78)$ & $4(100)$ \\
\hline
\end{tabular}

nucleus with a granular nucleolus, a little heterochromatin (Fig. 1), and a normal nuclear membrane, from which up to 7 inactive Golgi-like cisternae arose (Fig. 2). There was no apparent budding from the cisternae, but a few small coated and larger uncoated vesicles, 50 to $74 \mathrm{~nm}$ in diameter, occurred throughout the cytoplasm, and 1 to 3 unit membrane-bound lysosome-like bodies were seen in some sections (Fig. 2). Ribosomes were scattered throughout the cytoplasm (Fig. 2). In all host cell types, QC often occurred free in the cytoplasm but occasionally were found tight against the surface of the host cell nucleus, or host cell mitochondria, especially in haemocytes and myocytes. Extracellular QC, at the edge of myocytes, did not differ from those in VCT cells and haemocytes, but QC in myocytes lacked nuclear membrane-bound Golgi-like cisternae. One QC with 2 nuclei separated by inactive Golgi-like cisternae was observed in a VCT cell (see Fig. 18).

\section{Vesicular cells}

Vesicular cells (VC) were only observed in myocytes (Figs 3 to 6) or extracellularly near myocytes (Tables 1 \& 3). They lay within vacuoles, the membranes of which were tightly around the parasite, except in some places where irregular spaces containing flocculent material occurred between the parasite and host (Fig. 3). Similar irregular spaces with flocculent content occurred throughout nearby muscle. VC lacked nuclear membrane-bound Golgi-like arrays, the nuclear membrane was sometimes dilated to form a cisternal 
Table 4. Endosomal cells (EC); interaction with host cells and ultrastructural features. n: number examined; none: features that distinguish EC from quiescent cells (QC); aER: anastomosing endoplasmic reticulum; STBs: spherical thick-walled bodies

\begin{tabular}{|c|c|c|c|}
\hline & $\begin{array}{l}\text { VCT }(\%) \\
(\mathrm{n}=27)\end{array}$ & $\begin{array}{l}\text { Haemocytes }(\%) \\
(\mathrm{n}=13)\end{array}$ & $\begin{array}{l}\text { Extracellular }(\%) \\
\qquad(\mathrm{n}=5)\end{array}$ \\
\hline \multicolumn{4}{|l|}{ Host cell } \\
\hline Inside host cell nuclear membrane & $8(30)$ & $10(77)$ & $1(20)$ \\
\hline Apposition host cell mitochondria & $1(4)$ & $6(46)$ & \\
\hline \multicolumn{4}{|l|}{ Parasite } \\
\hline Normal nuclear membrane & $12(44)$ & $7(54)$ & $1(20)$ \\
\hline Dilated nuclear membrane & $13(48)$ & $6(46)$ & $4(80)$ \\
\hline Inclusion in nuclear membrane cisterna & $4(15)$ & $5(38)$ & \\
\hline Vesicle secreting into nuclear cisterna & $1(4)$ & $2(15)$ & $1(20)$ \\
\hline Membrane-bound Golgi & None & None & None \\
\hline Nuclear vacuole & $5(19)$ & & \\
\hline $\mathrm{aER}$ & $19(70)$ & $8(62)$ & $2(40)$ \\
\hline Granular material & $3(11)$ & $1(8)$ & \\
\hline STBs & $13(48)$ & $5(38)$ & \\
\hline Lysosome-like bodies & $4(15)$ & $4(31)$ & $1(20)$ \\
\hline Thick-walled endosomes & $20(74)$ & $10(77)$ & $3(60)$ \\
\hline Large vesicles & $27(100)$ & $12(92)$ & $4(80)$ \\
\hline Small coated vesicles & $26(96)$ & 12 (92) & 5 (100) \\
\hline Small uncoated vesicles & $22(81)$ & $10(77)$ & $5(100)$ \\
\hline
\end{tabular}

chamber (Fig. 4), and membranous ring-like inclusions occurred in the nuclear cisternal chamber (Fig. 4, inset a), or cytoplasm as looped structures (Fig. 4) of some VC. A few large vesicles were scattered throughout the cytoplasm (Figs 3 to 6), and rarely thick-walled ovoid vesicles occurred in some VC (Fig. 4). Host cell mitochondria often lay against the host cell membrane (Figs 4 to 6), $20 \mathrm{~nm}$ from the parasite surface, or in direct contact with it. Tube-like structures, 25 to $27 \mathrm{~nm}$ in diameter, passed from the mitochondria into the parasite cytoplasm, where many small coated and uncoated vesicles of similar appearance and size (20 to $50 \mathrm{~nm}$ ) occurred throughout the cytoplasm (Fig. 6), often in rows (Figs $3 \& 5$ ). Some tubes were associated with membranes that may have been the remnants of host cell mitochondria, suggesting that the contents of the mitochondrion had passed into the parasite cytoplasm (Fig. 6). A few VCs contained profiles of anastomosing endoplasmic reticulum (aER), between the nucleus and the plasma membrane (Fig. 4), and 1 to 2 lysosome-like bodies were observed. VC occasionally had a nuclear membrane cisternal chamber formed by dilatation of the outer nuclear membrane (Fig. 4).

\section{Endosomal cells}

Endosomal cells (EC) occurred in haemocytes, VCT, or were extracellular, but they were not observed in myocytes (Tables $1 \& 4$ ). They superficially resembled $\mathrm{QC}$, but differed in the possession of thick-walled ovoid endosome-like bodies (Figs 7 to 10), after which

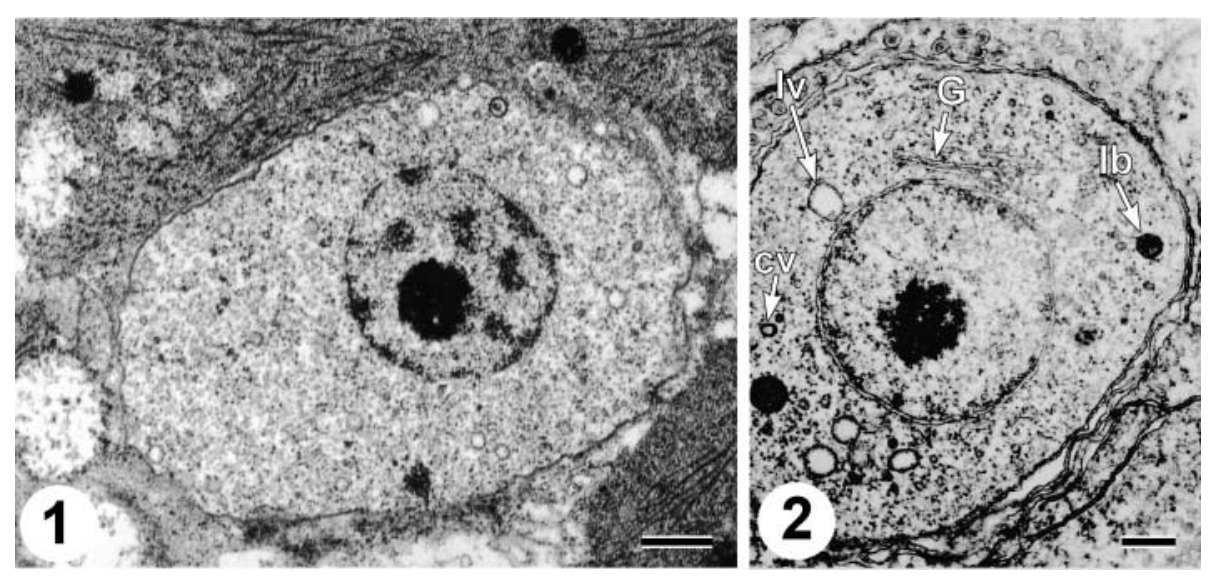

Figs 1 \& 2. Quiescent cells (QC) in Crassostrea gigas. Scale bars = $0.5 \mu \mathrm{m}$. Fig. 1. QC lying at the edge of myocytes, showing the lack of organelles, and some heterochromatin in the nucleus. Phosphate buffer. Fig. 2. Higher magnification of a $\mathrm{QC}$, showing the Golgi-like cisternae (G), a few large vesicles (lv), small coated vesicles (cv), lysosome-like bodies (lb) and numerous ribosomes scattered throughout the cytoplasm. VCT of labial palps, Millonig's buffer 

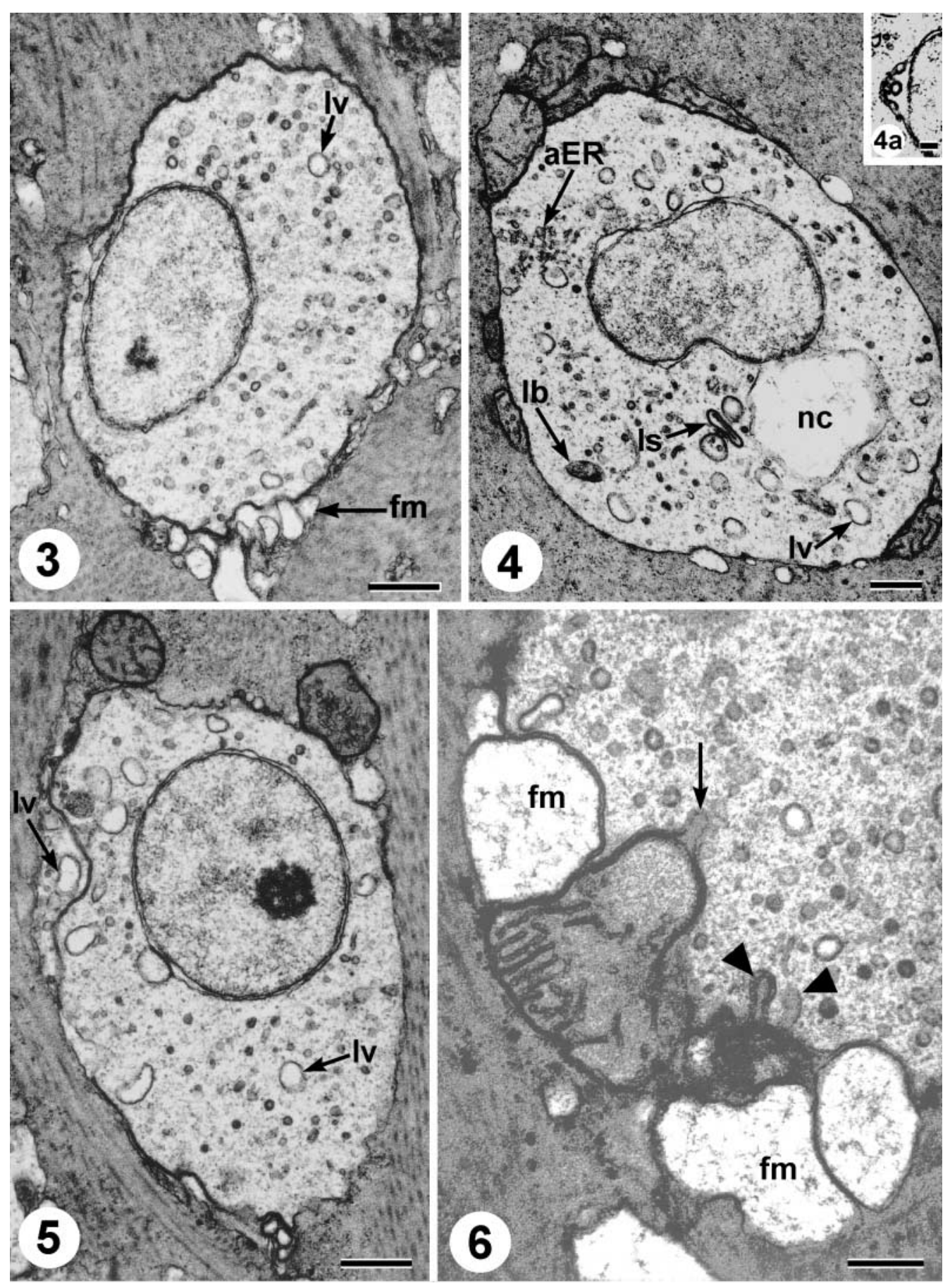

Figs 3 to 6. Vesicular cells (VC) in Crassostrea gigas, myocytes, phosphate buffer. Fig. 3. VC with a normal nuclear membrane, the edge of a nucleolus, many small coated and uncoated vesicles, some in chain-like configurations, and a few large vesicles (lv). Note the flocculent extracellular material (fm) next to the parasite membrane, and elsewhere in the host cells. Scale bar $=0.5 \mu \mathrm{m}$. Fig. 4. VC showing host cell mitochondria against the parasite surface. The nuclear membrane is dilated into a nuclear membrane cisternal chamber (nc), and in the cytoplasm, a looped structure (ls) and tubules suggestive of anastomosing endoplasmic reticulum (aER) are evident. A few large vesicles (lv) and lysosome-like bodies (lb) lie within the parasite. Scale bar $=0.5 \mu \mathrm{m}$. Fig. 4a (inset) the edge of a VC nucleus with a dilated nuclear membrane containing a circular structure. Scale bar $=0.1 \mu \mathrm{m}$. Fig. 5. VC with a normal nuclear membrane, host cell mitochondria against the parasite surface, and similar looking large

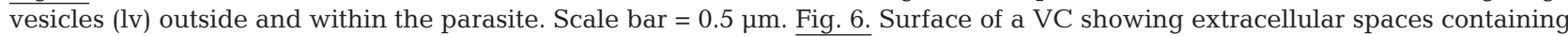
flocculent material (fm), and a mitochondrion apparently pushing into the VC cytoplasm. From the mitochondrion, a tube-like structure (arrow) extends into the cytoplasm, and 2 other tubes (arrowheads) can be seen extending from a dense necrotic structure nearby. Scale bar $=0.25 \mu \mathrm{m}$ 
they were named, and the presence of a well-developed aER (Figs 7 \& 8). Also, unlike QC and VC, EC contained spherical thick-walled bodies, here called STBs (Figs 7, 9 \& 10). The wall of STBs was $16 \mathrm{~nm}$ thick, and composed of repeating rod-like units $20 \mathrm{~nm}$ long, comprising an outer less dense portion $13 \mathrm{~nm}$ long and inner more osmiophilic portion $7 \mathrm{~nm}$ long, and $6 \mathrm{~nm}$ wide, giving the inner surface a spiny or furry appearance. Sometimes it was difficult to distinguish STBs from the thick-walled endosome-like bodies (Figs 8 \& 9), which were of similar size (Table 1). Thick-walled endosome-like bodies usually lacked the outer membrane of STBs and did not contain internal osmophilic structures. EC lacked the distinct but apparently inactive nuclear membrane-bound Golgi of $\mathrm{QC}$ but in a few EC, a tubulovesicular Golgi-like complex was observed (Fig. 7). Large complexes of smooth and rough aER (Figs 7, 8, 11 \& 12), joined the nuclear mem-

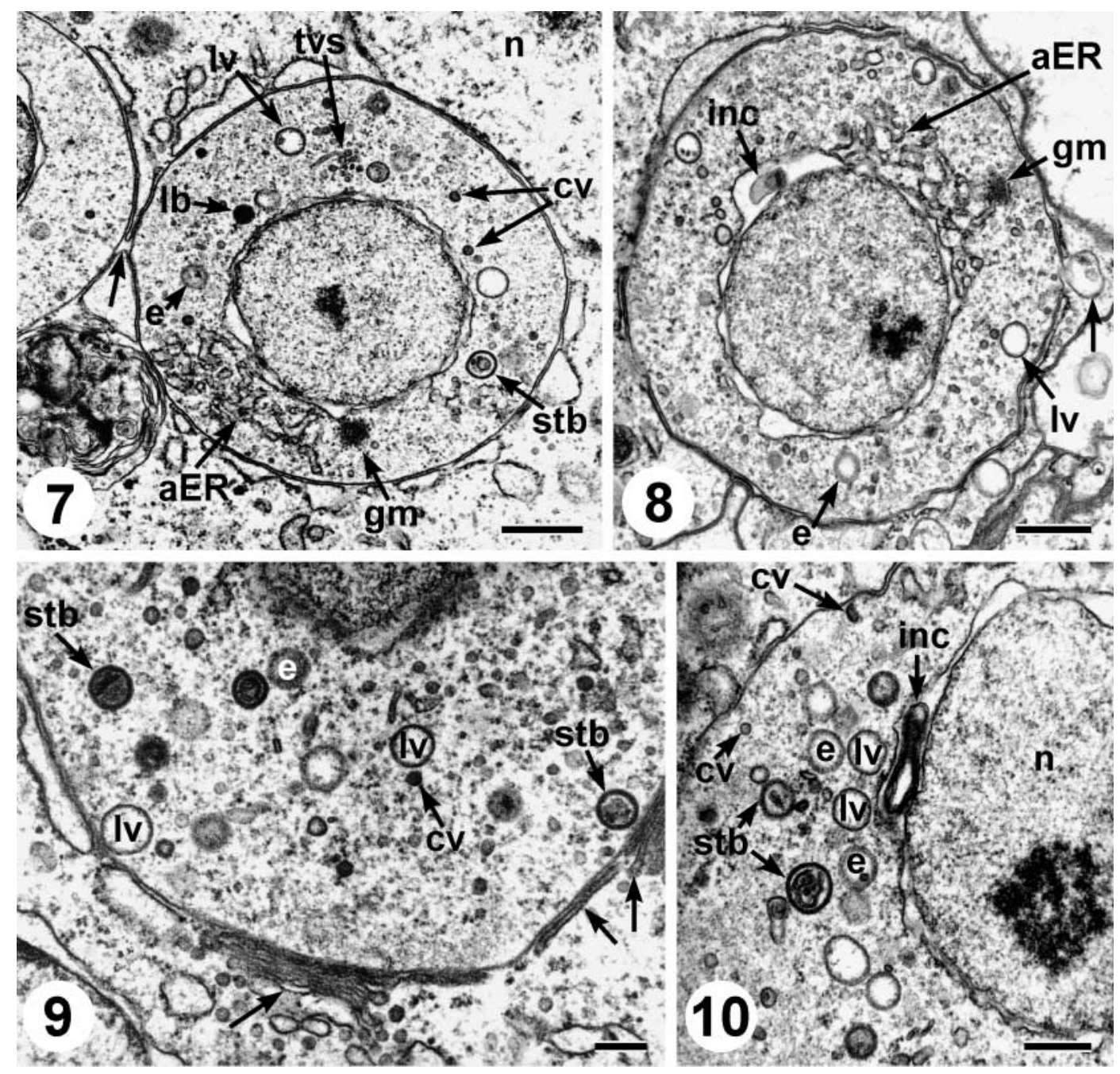

Figs 7 to 10. Endosomal cells (EC) in Crassostrea gigas, phosphate buffer. Fig. 7. An EC, and part of another EC within the same vacuole or phagosome (arrow) in a hyalinocyte. Note the close contact with the host cell nucleus (n). The EC has a slightly dilated nuclear membrane, anastomosing endoplasmic reticulum (aER), associated with fine granular material (gm), a Golgi-like tubulovesicular structure (tvs), spherical thick-walled body (stb), large vesicles (lv), small coated vesicles (cv), thick walled endosome-like bodies and a lysosome-like body. Scale bar $=0.5 \mu \mathrm{m}$. Fig. 8. Another EC with a dilated nuclear membrane containing an inclusion (inc), and showing a thick-walled endosome-like body (e), aER and associated granular material (gm), large vesicles (lv) and vesicles that apparently passed through from the EC into the host cell cytoplasm (arrow). Host cell type uncertain. Scale bar $=0.5 \mu \mathrm{m}$. Fig. 9. Cytoplasm of an EC showing the similarities in size and shape between STBs (stb), thick-walled endosomelike bodies (e), and large vesicles (lv), one of which appears to have formed at the parasite surface. Note the small coated vesicles (cv) and various other tubules in the cytoplasm of the EC and haemocyte Golgi cisternae (arrows) flattened on the parasite surface. Scale bar $=0.25 \mu \mathrm{m}$. Fig. 10. Part of another EC with a dilated nuclear membrane containing a looped membranous structure (inc), and cytoplasm with several thick-walled endosome-like bodies (e), STBs (stb), and large (lv) and small (cv) vesicles. Host cell type uncertain. Scale bar $=0.25 \mu \mathrm{m}$ 


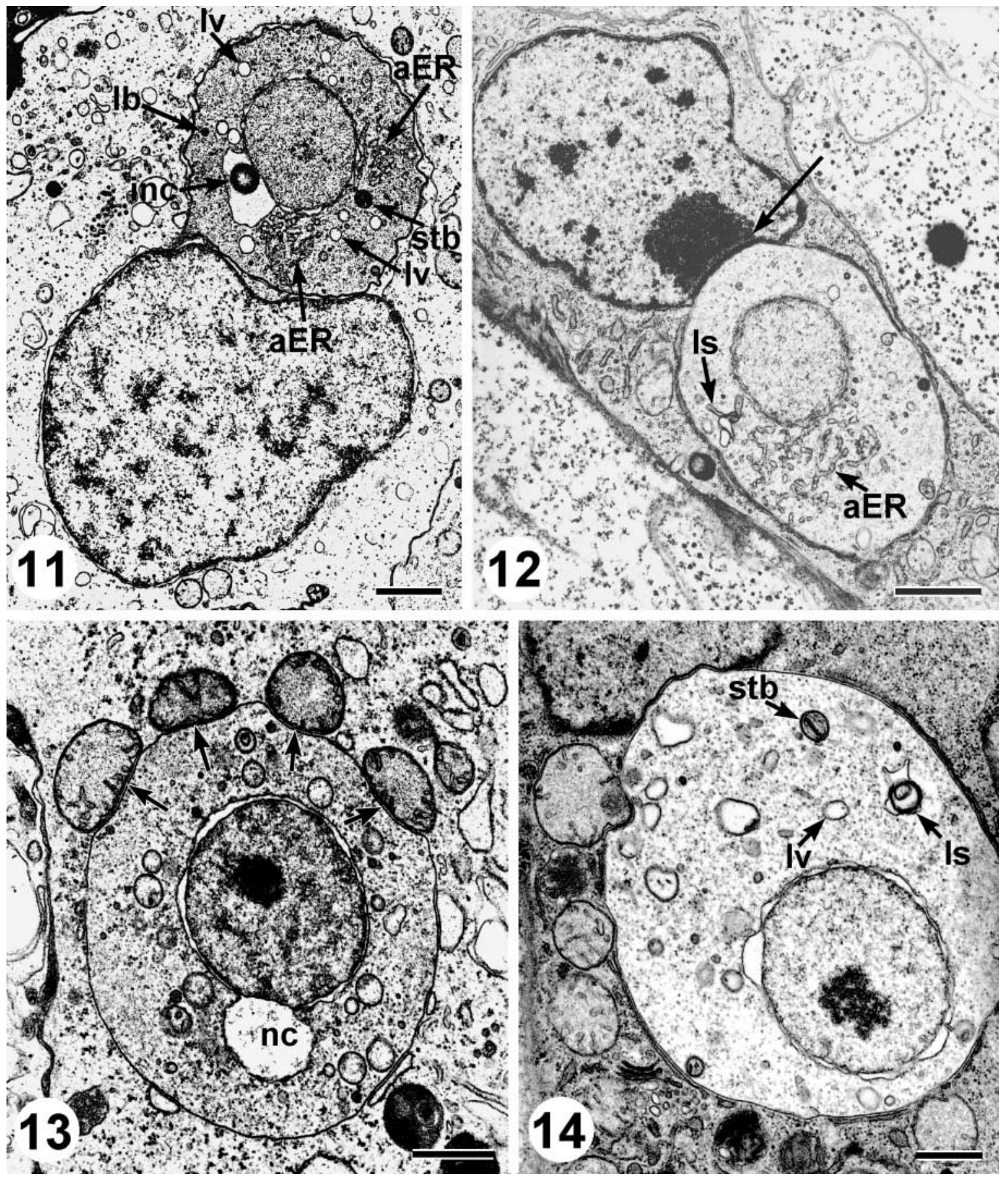

Figs 11 to 14. Endosomal cells (EC) and the host cell nucleus and mitochondria in Crassostrea gigas, phosphate buffer. Fig. 11. EC lying within a pocket in the nuclear membranes of a VCT cell. Features evident in this EC include a nuclear membrane cisternal chamber containing a circular inclusion (inc), anastomosing endoplasmic reticulum (aER), a spherical thick-walled body (stb), large vesicles (lv) and a lysosome-like body (lb). Scale bar $=1.0 \mu \mathrm{m}$. Fig. 12. EC in a hyalinocyte, between $2 \mathrm{VCT}$ cells. The EC is against, but not within the haemocyte nuclear membrane, but dark granular material similar to haemocyte nucleolar granular matrix occurs in the space between the nucleolus and the EC (arrow). The aER is extensive in this specimen and a looped membranous structure (ls) occurs in the cytoplasm. Scale bar $=1.0 \mu \mathrm{m}$. Fig. 13. EC in a hyalinocyte, showing 4 mitochondria so tight against the parasite surface that the surface is depressed at the point of contact. Note the dilation of the nuclear membrane of the $\mathrm{EC}$ to form a nuclear membrane cisternal chamber (nc). Scale bar $=0.5 \mu \mathrm{m}$. Fig. 14. Another EC in a hyalinocyte showing 3 mitochondria at different stages of association, from close association (bottom), slight surface depression (middle), and pushing into the parasite cytoplasm (top). The latter has reduced cristae and appears to be abnormal. This EC also contains looped membranous structure (ls), a STB (stb), and large vesicles (lv) in the cytoplasm. Scale bar $=0.5 \mu \mathrm{m}$ 
brane to the plasma membrane (Figs $7,11 \& 12$ ). Fine osmiophilic granules 13 to $15 \mathrm{~nm}$ in diameter, were occasionally observed lying next to these complexes (Figs 7 \& 8). A few similar small circular uncoated and coated vesicles were scattered in the cytoplasm (Figs 7 \& 9). Ovoid osmophilic membrane-bound vesicles resembling lysosomes occurred in some cells with well-developed aER. Other large vesicles in the cytoplasm appeared to be passing out of the parasite (Fig. 9 ), and their content resembled material lying outside and against the surface of the parasite (Figs $8 \& 9$ ).

In haemocytes, EC were frequently observed tight against the host nucleus and sometimes between the nuclear membranes (Figs 7, 11 \& 12). Rarely, the haemocyte nucleolus lay against the EC, with dark material in the space between the nucleolus and the EC (Fig. 12). Haemocyte mitochondria often closely surrounded the EC, with their membranes $20 \mathrm{~nm}$ apart (Fig. 13), and sometimes appeared to be pushing into the EC (Fig. 14). The haemocyte Golgi cisternae were also observed flattened on the parasite surface (Fig. 9).

In haemocytes and VCT, looped membranous structures occurred in the cytoplasm of some EC (Fig. 14), and in others, similar membranous looped structures occurred in nuclear membrane cisternal chambers (Figs 10 \& 11). The structures in the cisternal chambers varied from a loop consisting of 2 dark membranes separated by a clear space (Fig. 15a), to duplication of the dark membranes (Fig. 15b,c) and multiplication of the loops (Fig. 15d). In width they varied from $16 \mathrm{~nm}$ for the dark membrane with a clear space of 7 to $8 \mathrm{~nm}$ in Fig. 15a, to $11 \mathrm{~nm}$ for the dark membranes with a clear space of $6 \mathrm{~nm}$ in Figs $15 \mathrm{~b}$ to d. Rarely in haemocytes, but more frequently in $\mathrm{VCT}$, the nucleolus of EC disaggregated into a semi-circle of $\sim 10$ dense structures, possibly chromosomes (Fig. 16). Concurrently, in some cells, the nucleus contained a circular ring-shaped structure (Fig. 17), but no microtubules were apparent connecting the ringshaped structure to the putative chromosomes. Several binucleate (Fig. 18) and a single multinucleate EC (Fig. 19) were only observed in the VCT, but karyokinesis and cytokinesis were not observed.

\section{DISCUSSION}

\section{Parasite taxonomic affinities}

The appearance of QC in haemocytes superficially resemble Bonamia sp. in size and the appearance of Golgi-like cisternae arising from the nuclear membrane (Dinamani et al. 1987, Hine 1991, Hine \& Wesney 1994a). There are, however, 2 notable exceptions; the lack of haplosporosomes and absence of mitochondria. These appear to be fundamental differences, but they may not be. Haplosporosomes occur in haplosporidians (Haplosporidium, Minchinia, Bonamia, Urosporidium), paramyxeans (Paramyxa, Marteilia, Marteilioides), and the vegetative stages of myxozoans (Morris et al. 2000). The latter are multicellular organisms, now regarded as cnidarians, and paramyxeans appear multicellular during sporulation. Possession of haplosporosomes, by itself, is of no phylogenetic significance, and therefore absence of haplosporosomes, by itself, is of no phylogenetic significance.

Also, the amitochondriate condition of Mikrocytos mackini does not necessarily mean that it has never possessed mitochondria, or that it lacks mitochondrial equivalents or mitochondrial genes. Basal eukaryote groups (metamonads, parabasalids, microsporidians and other fungi) are amitochondriate, and apparently they diverged early in protist evolution, before acquisition of an endosymbiont from which mitochondria derive. However, the genes encoding mitochondrial proteins have also been found in amitochondriate species (Germot et al. 1997, Peyretaillade et al. 1998), sometimes associated with double membrane boundorganelles called hydrogenosomes (Benchimol et al.
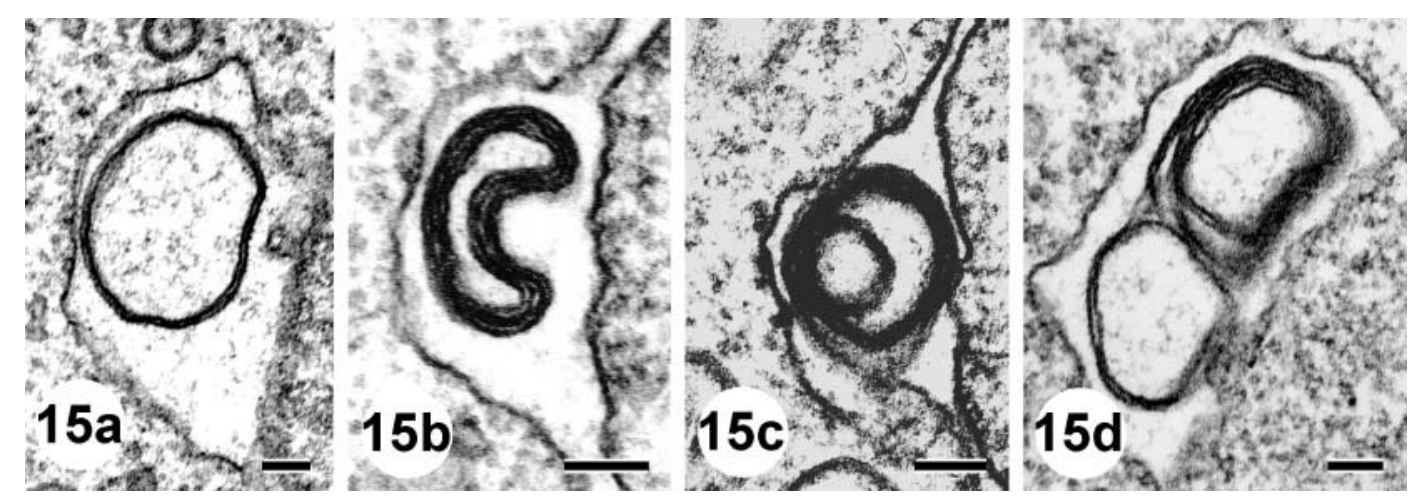

Fig. 15. Crassostrea gigas, phosphate buffer. Examples of looped membranous structures in the nuclear membrane cisternal chamber. Scale bars $=0.1 \mu \mathrm{m}$ 

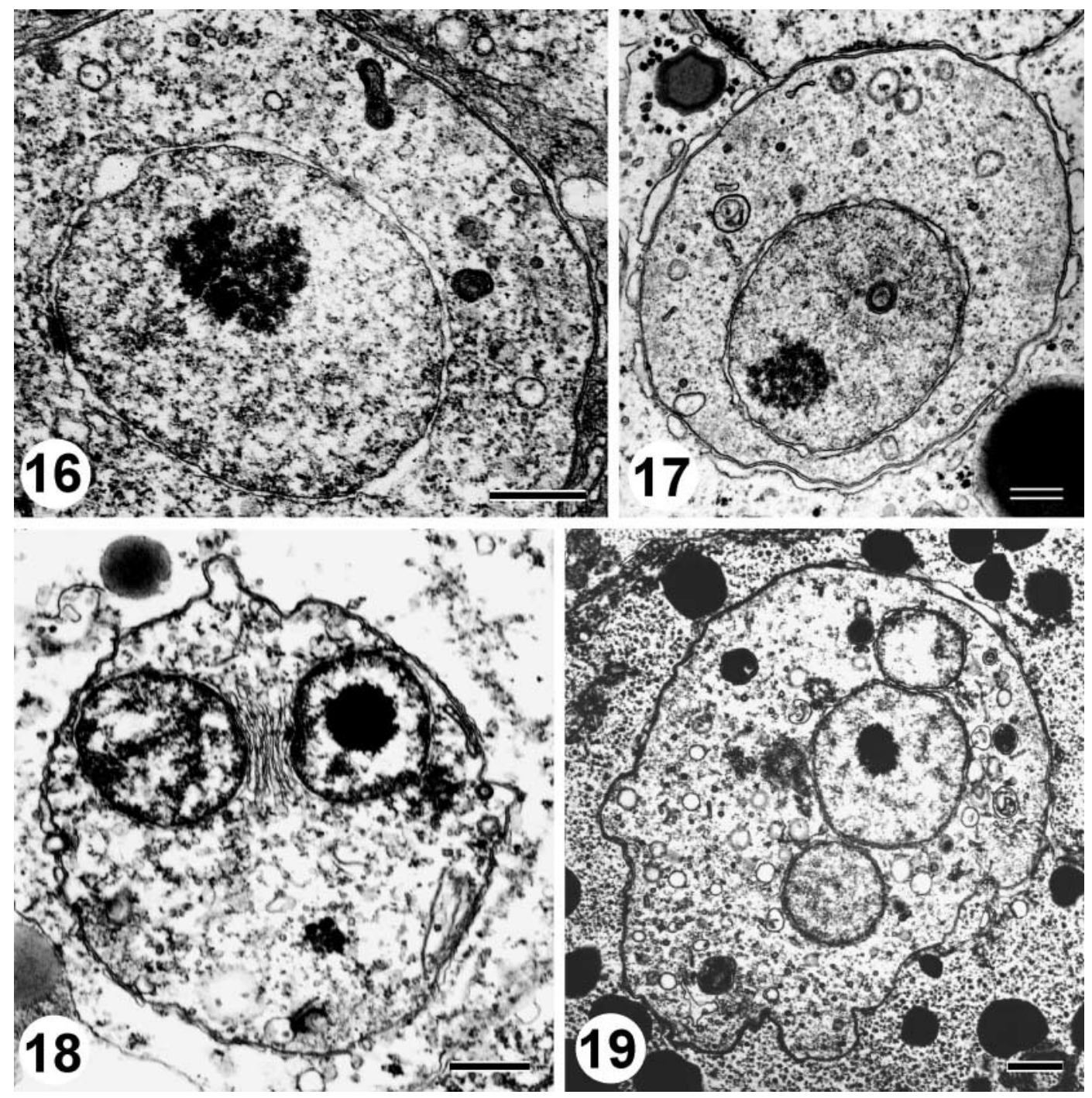

Figs 16 to 19. Mitosis of Mikrocytos mackini in Crassostrea gigas, phosphate buffer. Scale bars $=0.5 \mu \mathrm{m}$. Fig. 16. Nucleus of an extracellular EC showing apparent disaggregation of the EC nucleolus into dense bodies, possibly chromosomes. Fig. 17. Nucleus of an EC in VCT containing a ring-like structure. Fig.18. Binucleate stage showing well formed Golgi-like cisternae between the 2 nuclei. Fig. 19. Trinucleate section in a VCT cell

1996a,b, Biagini et al. 1997). Consequently mitochondria and hydrogenosomes likely derived from endosymbionts (Biagini et al. 1997). However, the same proteins occur in the cytoplasm of basal eukaryote Giardia lamblia (Roger et al. 1999), which lacks mitochondria and hydrogenosomes, and all extant eukaryotes probably derived from an endosymbiont-bearing ancestor (Martin \& Müller 1998, Gray et al. 1999). The amitochondriate state of the basal groups is due to their parasitic habit, which negates the need for such organelles, and in M. mackini may be due to the secondary loss of pre-existing mitochondria.

Alternatively, Mikrocytos mackini may possess organelles equivalent to mitochondria, hydrogenosomes, microbodies and peroxisomes, all of which are thought to be derived from endosymbionts. However, neither the STBs nor any other cytoplasmic structure can be identified as mitochondrial equivalents, as they all lack the double membrane characteristic of mitochondria, hydrogenosomes and microbodies (Fiskin \& Garrison 1986, Van der Giezen 1997), and their prokaryotebearing ancestor (Gray et al. 1999, Müller \& Martin 1999). Therefore there is no identifiable organelle that may be the equivalent of mitochondria.

Some of the few cytoplasmic inclusions observed here in EC can be tentatively identified as organelles seen in other protozoans. The thick-walled endosomelike bodies resemble the endosomes deriving from the 
flagellar pocket in trypanosomes (Clayton et al. 1995). However, trypanosome endosomes have bristles and spines on the cytoplasmic surface, and a fuzzy layer on the lumenal surface (Duszenko et al. 1988), similar to the STBs observed here, which may suggest that STBs and thick-walled endosome-like bodies of Mikrocytos mackini are related. The fuzzy lumenal coat of trypanosome endosomes is considered variant surface glycoprotein, derived from the surface of the plasma membrane (Shapiro \& Webster 1989). In some micrographs the thick-walled endosome-like bodies of $M$. mackini occurred in chains between the plasma and nuclear membranes, possibly indicating a direct connection between the 2 compartments. The size and shape of thick-walled endosome-like bodies and large vesicles of $\mathrm{EC}, \mathrm{QC}$ and $\mathrm{VC}$ were also similar, but their relationship is unclear.

Vesicular connective tissue cells (Leydig cells) of oysters are glycogen storage cells, with a few granules and mitochondria, and therefore EC may have been endocytosing glycogen. The identity and role of the 93 to $50 \mathrm{~nm}$ coated vesicles seen in the cytoplasm of EC are unknown. They may be coated vesicles transporting proteins from the ER to the tubulovesicular Golgilike complexes, but this is doubted because they appeared too widely spread to be travelling from adjacent organelles. They may be clathrin-coated vesicles travelling from the Golgi-like tubulovesicular structure to the plasma membrane, or to lysosomes (Becker \& Melkonian 1996). Alternately, the small coated and uncoated vesicles of $\mathrm{VC}$ appear to contain material obtained from the host cell mitochondria (Fig. 6). Overall, Mikrocytos mackini has a large amount of aER connecting the nuclear and plasma membranes and simple Golgi-like arrays and tubulovesicular structures and lysosome-like and endosome-like bodies, which could be interpreted as being primitive, or the reduced basic apparatus of a highly adapted obligate parasite, or both.

The method of entry of Mikrocytos mackini into host cells is unknown, but entry into haemocytes is probably by phagocytosis, as in Bonamia spp. (Chagot et al. 1992, Hine \& Wesney 1994b). The small dense lysosome-like bodies seen in some cells may be used to lyse host cells, effecting egress. The haemocytes containing parasites were the cells of Crassostrea gigas identified as hyalinocytes by Auffret (1989). M. mackini was also seen in cells with granules, which were VCT cells with diminished cytoplasm, resulting in the granules of these cells surrounding, but not interacting with, the parasite. Within the cell the parasite was usually enveloped by a tight membrane, presumably derived from the host. Small pockets containing flocculent material were often seen between the host membrane and $\mathrm{VC}$ and EC stages, but the origin of this material was unclear. Except in one cell (Fig. 8), there was no evidence of release of vesicles, enlargement of the enveloping membrane and formation of a parasitophorous vacuole, as in Bonamia sp. (Hine \& Wesney 1994b) and other intracellular parasites (Sinai \& Joiner 1997, Corsaro et al. 1999). The vacuole in which M. mackini lies may not therefore be regarded as a parasitophorous vacuole. Despite this, host cell granules appeared unable to release their content into the space surrounding the parasite.

It is not possible, because of the lack of organelles and division patterns characteristic of other protozoan parasites, to determine the phylogenetic affinities of Mikrocytos mackini. Even though the lack of haplosporosomes and mitochondria, or their equivalents, may not exclude M. mackini from the Haplosporidia, the absence of such characteristic features of the haplosporidians, such as the diplokaryotic stage with an internuclear chamber, and the persistent mitotic intranuclear spindle (Perkins 1968, 1975, Hine 1991), exclude $M$. mackini from that group, presently. Although the ultrastructure of Mikrocytos roughleyi has yet to be published, it has many of the features of haplosporidians, and clearly belongs in that group (Hine \& Cochennec-Laureau unpubl. obs.). As M. mackini was described before $M$. roughleyi, it will retain that binomial, and M. roughleyi will have to be re-named.

\section{Host:parasite relationships}

There was a close association between $\mathrm{QC}$ and host cell mitochondria in haemocytes and muscle (less so in $\mathrm{VCT}$ ), between VC and host cell mitochondria in muscle, and between EC and mitochondria in haemocytes (and less so in VCT). Vesicular cells appeared to endocytose the contents of myocyte mitochondria (Fig. 6), and haemocyte mitochondria appeared to push into EC (Fig. 15). This association is supported by the distance of $20 \mathrm{~nm}$ between the membranes of the mitochondria and the parasite. Repulsive interactions between negatively charged membranes normally result in an exclusion zone of 30 to $50 \mathrm{~nm}$ between membranes (Sinai et al. 1997). This distance is broached by host cell mitochondria and the surface of Mikrocytos mackini, suggesting that the mitochondria are actively pushing against, or attracted to, the parasite.

The association of host cell mitochondria with intracellular parasites also occurs in apicomplexan infections (Lindsay et al. 1993, Pimenta et al. 1994, Sinai et al. 1997), and some microsporidian infections (Durfort et al. 1987, Cali \& Owen 1990). In apicomplexans, the interaction depends on the parasite species and host cell type (Lingelbach \& Joiner 1998). Plasmodium spp. provide the host cell with ATP (Jacobasch et al. 1990), 
whereas Toxoplasma gondii takes ATP and possibly other proteins from host cell mitochondria (Sinai et al. 1997, Sorensen et al. 1997). In this study, mitochondrial substance appeared to pass from the host cell to the parasite, suggesting Mikrocytos mackini may derive ATP and mitochondrial enzymes from its host.

In all infected cell types, but particularly QC and EC in haemocytes, Mikrocytos mackini frequently lay either close to the nucleus, or between the membranes in the perinuclear space, with dilatation of the outer nuclear membrane of the host cell. Both proliferation of the outer nuclear membrane and residence in the perinuclear space are features of some rickettsial infections (Silverman 1984). Mitochondria are almost certainly derived from rickettsial organisms (Andersson et al. 1998, Lang et al. 1999, Müller \& Martin 1999), and both produce oxidants, which can damage membranes (Eremeeva \& Silverman 1998). Although nuclear membrane dilatation in both the parasite and host cell may be due to an oxidant release by $\mathrm{VC}$ and $\mathrm{EC}, 2$ observations call this interpretation into question. Firstly, in rickettsial infections oxidant damage affects the membranes of other organelles, such as endoplasmic reticulum (ER) and mitochondria (Silverman 1984). This was not observed here. Secondly, in $M$. mackini, dilatation of the outer nuclear membrane appears to be associated with the presence of looped structures, suggesting that dilatation is part of a normal process.

The association of the parasite with the nucleus also occurs in some microsporidian infections (Beard et al. 1990, Cali \& Owen 1990). The microsporidian Enterocytozoon closely associates with the host cell nucleus, and with host cell mitochondria (Cali \& Owen 1990). It also has electron-lucent inclusions (ELI) next to the parasite nucleus, which superficially resemble the electron-lucent perinuclear areas in Mikrocytos mackini, in which looped membranous structures were observed. In Enterocytozoon, the early stages of development of electron-dense disc-like structures, which resemble the looped structures in M. mackini, occurs in the cytoplasm, and they come to lie at the edge of the ELIs (Cali \& Owen 1990). However, such similarities may be co-incidental, and other features of microsporidian development were not observed.

When there was close apposition of the host cell nucleolus with the parasite in the perinuclear space, osmiophilic substance filled the space between the host inner nuclear membrane and the parasite. The fine granular appearance of the substance was similar to that of the nucleolus, suggesting it was passing out of the nucleolus toward the parasite. Bearing in mind the structure and function of the nucleolus (Scheer \& Hock 1999), the substance may be ribosomal subunits.

\section{Hypothetical life-cycle}

Three different forms of Mikrocytos mackini could be distinguished ultastructurally, but there was an overlap in features between QC and $\mathrm{VC}$, between $\mathrm{VC}$ and EC (e.g., Fig. 4), and between EC and QC (e.g., Fig. 14). One interpretation is that $M$. mackini acquires a morphological stage suited to its energy acquisition opportunities. Another interpretation is that this parasite cycles through the various stages during its development. Although it may be interpreted that EC change to $\mathrm{VC}, \mathrm{VC}$ change to $\mathrm{QC}$, and $\mathrm{QC}$ change to $\mathrm{EC}$, this is unlikely because of the pattern of parasite multiplication. Early division stages (putative chromosomes [Figs $14 \& 16$ ] and ring-shaped structure [Fig. 17]) and bi- and multi-nucleate forms were only observed in stages transitional between EC and QC and one bi-nucleate $\mathrm{QC}$ was found in the VCT (Fig. 18). The logical interpretation is that $\mathrm{QC}$ from the VCT travel in haemocytes to the adductor or heart muscles, where they change to $\mathrm{VC}$, which later change to $\mathrm{EC}$ in the process of leaving the muscle and enter haemocytes. While travelling to the VCT in haemocytes or extracellularly, mitosis begins in EC and is completed in the VCT where the daughter generation changes to QC.

Given this developmental interpretation, the following hypothesis is presented (Fig. 20). Except for ap-

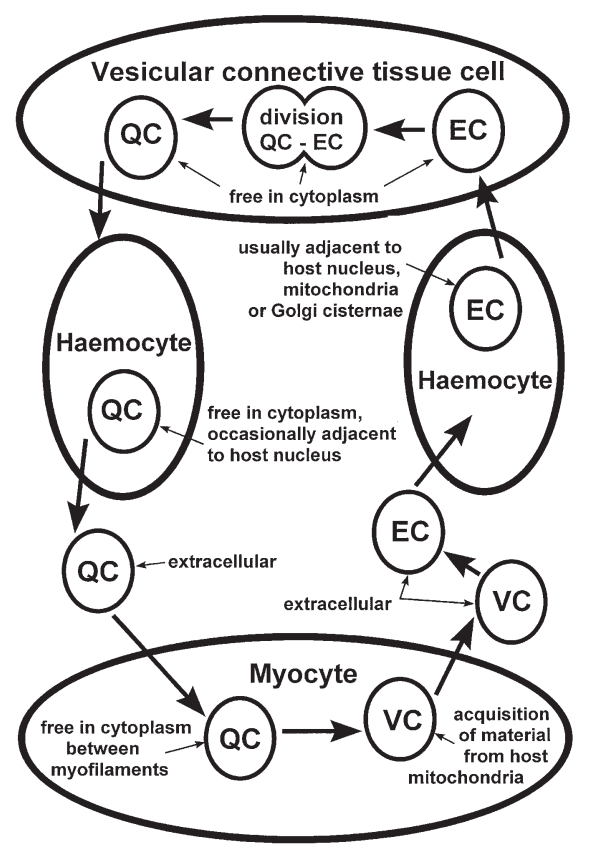

Fig. 20. Proposed developmental cycle of Mikrocytos mackini indicating host cell type and host organelle affiliations for the 3 recognised morphological forms consisting of quiescent cell (QC), vesicular cell (VC) and endosomal cell (EC). See Table 1 for the characteristics of each of the morphological forms 
parently inactive Golgi-like cisternae arising from the nuclear membrane, the QC form lacks nearly all the cytoplasmic organelles of a eukaryotic cell, such as mitochondria, endoplasmic reticulum, and a functioning Golgi, and energy reserves such as glycogen granules or lipid droplets. Therefore QC in the VCT travel to the adductor and heart muscles in haemocytes, possibly acquiring ATP from mitochondria. In the myocytes they become VC and endocytose the contents of myocyte mitochondria, acquiring ATP and other proteins. In transit in haemocytes between the muscle and the VCT, the EC maintain close contact with haemocyte mitochondria, obtain ribonucleoproteins from the haemocyte nucleolus, and develop extensive aER. Back in the VCT, EC begin endocytosing glycogen, using the ATP to effect glycolysis, they develop a small tubulovesicular Golgi-like complex, and some protein synthesis and growth occur. The EC divide by karyokinesis, presumably followed by cytokinesis, and the daughter cells develop to QC.

\section{LITERATURE CITED}

Andersson SG, Zomorodipour A, Andersson JO, SicheritzPonten T, Alsmark UC, Podowski RM, Naslund AK, Eriksson AS, Winkler HH, Kurland CG (1998) The genome sequence of Rickettsia prowazekii and the origin of mitochondria. Nature 396:133-140

Auffret M (1989) Comparative study of the hemocytes of two oyster species: the European flat oyster, Ostrea edulis (Linnaeus, 1750) and the Pacific oyster, Crassostrea gigas (Thunberg, 1793). J Shellfish Res 8:367-373

Balouet G, Poder M, Cahour A (1983) Haemocytic parasitosis: morphology and pathology of lesions in the French flat oyster, Ostrea edulis L. Aquaculture 34:1-14

Beard CB, Butler JF, Becnel JJ (1990) Nolleria pulicis n. gen., n. sp. (Microsporida: Chytridiopsidae), a microsporidian parasite of the cat flea, Ctenocephalides felis (Siphonaptera: Pulicidae). J Protozool 37:90-99

Becker B, Melkonian M (1996) The secretory pathway of protists: spatial and functional organization and evolution. Microbiol Rev 60:697-721

Benchimol M, Almeida JC, de Souza W (1996a) Further studies on the organization of the hydrogenosome in Tritrichomonas foetus. Tissue Cell 28:287-299

Benchimol M, Johnson PJ, de Souza W (1996b) Morphogenesis of the hydrogenosome: an ultrastructural study. Biol Cell 87:197-205

Biagini GA, Finlay BJ, Lloyd D (1997) Evolution of the hydrogenosome. FEMS Microbiol Lett 155:133-140

Bower SM, McGladdery SE, Price IM (1994) Synopsis of infectious diseases and parasites of commercially exploited shellfish. Ann Rev Fish Dis 4:1-199

Bower SM, Hervio D, Meyer GR (1997) Infectivity of Mikrocytos mackini, causative agent of Denman Island disease in Pacific oysters Crassostrea gigas, to various species of oysters. Dis Aquat Org 29:111-116

Brehélin M, Bonami JR, Cousserans F, Vivarès CP (1982) Existence de formes plasmodiales vraies chez Bonamia ostreae parasite de l'huître plate Ostrea edulis. CR Acad Sci Paris 295:45-48
Cali A, Owen RL (1990) Intracellular development of Enterocytozoon, a unique microsporidian found in the intestine of AIDS patients. J Protozool 37:145-155

Chagot D, Boulo V, Hervio D, Mialhe E, Mourton C, Grizel H (1992) Interactions between Bonamia ostreae (Protozoa: Ascetospora) and hemocytes of Ostrea edulis and Crassostrea gigas (Mollusca: Bivalvia): entry mechanisms. J Invertebr Pathol 59:241-249

Clayton C, Häusler T, Blattner J (1995) Protein trafficking in kinetoplastid Protozoa. Microbiol Rev 59:325-344

Corsaro D, Venditti D, Padula M, Valassina M (1999) Intracellular life. Crit Rev Microbiol 25:39-79

Dinamani P, Hine PM, Jones JB (1987) Occurrence and characteristics of the haemocyte parasite Bonamia sp. in the New Zealand dredge oyster Tiostrea lutaria. Dis Aquat Org 3:37-44

Durfort M, Valero JG, Poquet M (1987) Particular distribución de las mitocondrias de Myticola intestinalis (Crustacea, Copepoda) en células parasitadas por Unicaryon mytilicolae (Microspora, Unikaryonidae). Rev Ibér Parasitol (Spec. Vol):1-11

Duszenko M, Ivanov IE, Ferguson MAJ, Plesken H, Cross GAM (1988) Intracellular transport of a variant surface glycoprotein in Trypanosoma brucei. J Cell Biol 106:77-86

Eremeeva ME, Silverman DJ (1998) Rickettsia rickettsii infection of the EA.hy 926 endothelial cell line: morphological response to infection and evidence for oxidative injury. Microbiology 144:2037-2048

Farley CA, Wolf PH, Elston RA (1988) A long-term study of 'microcell' disease in oysters with a description of new genus Mikrocytos (g.n.), and two new species, Mikrocytos mackini (sp.n.) and Mikrocytos roughleyi (sp. n.). Fish Bull 86:581-593

Fiskin AM, Garrison RG (1986) Double-membraned vesicles and their possible role in the ontogeny of microbodies of Basidiobolus haptosporus. Ann Inst Pasteur Microbiol 137A:15-31

Germot A, Philippe H, Guyader H (1997) Evidence for loss of mitochondria in Microsporidia from a mitochondrial-type HSP70 in Nosema locustae. Mol Biochem Parasitol 87: 159-168

Gray MW, Burger G, Lang BF (1999) Mitochondrial evolution. Science 283:1476-1481

Hervio D, Bower SM, Meyer GR (1996) Detection, isolation, and experimental transmission of Mikrocytos mackini, a microcell parasite of Pacific oysters Crassostrea gigas (Thunberg). J Invertebr Pathol 67:72-79

Hine PM (1991) Ultrastructural observations on the annual infection pattern of Bonamia sp. in flat oysters Tiostrea chilensis. Dis Aquat Org 11:163-171

Hine PM (1992) Ultrastructural and ultracytochemical observations on Bonamia sp. in oysters (Tiostrea chilensis), with a consideration of organelle function. Aquaculture 107: 175-183

Hine PM, Wesney B (1992) Interrelationships of cytoplasmic structures in Bonamia sp. (Haplosporidia) infecting oysters Tiostrea chilensis: an interpretation. Dis Aquat Org 14: 59-68

Hine PM, Wesney B (1994a) The functional cytology of Bonamia sp. (Haplosporidia) infecting oysters (Tiostrea chilensis): an ultracytochemical study. Dis Aquat Org 20:207-217

Hine PM, Wesney B (1994b) Interaction of phagocytosed Bonamia sp. (Haplosporidia) with haemocytes of oysters (Tiostrea chilensis). Dis Aquat Org 20:219-229

Jacobasch G, Buckwitz D, Gerth C, Thamm R (1990) Regulation of the energy metabolism of Plasmodium berghei. Biomed Biochim Acta 49:289-294 
Lang BF, Seif E, Gray MW, O'Kelly CJ, Burger G (1999) A comparative genomics approach to the evolution of eukaryotes and their mitochondria. J Eukaryot Microbiol 46:320-326

Lindsay DS, Mitschler RR, Toivio-Kinnucan MA, Upton SJ, Dubey JP, Blagburn BL (1993) Association of host cell mitochondria with developing Toxoplasma gondii tissue cysts. Am J Vet Res 54:1663-1667

Lingelbach K, Joiner KA (1998) The parasitophorous membrane surrounding Plasmodium and Toxoplasma: an unusual compartment in infected cells. J Cell Sci 111: $1467-1475$

Martin W, Müller M (1998) The hydrogen hypothesis for the first eukaryote. Nature 392:37-41

Morris DJ, Adams A, Richards RH (2000) Observations on the electron-dense bodies of the PKX parasite, agent of proliferative kidney disease in salmonids. Dis Aquat Org 39: 201-209

Müller M, Martin W (1999) The genome of Rickettsia prowazekii and some thoughts on the origin of mitochondria and hydrogenosomes. Bioessays 21:377-381

Perkins FO (1968) Fine structure of the oyster pathogen Minchinia nelsoni (Haplosporida, Haplosporidiidae). J Invertebr Pathol 10:287-307

Perkins FO (1975) Fine structure of the haplosporidan KERN$S T A B$, a persistent, intranuclear mitotic apparatus. J Cell Sci 18:327-346

Peyretaillade E, Broussolle V, Peyret P, Metenier G, Gouy M, Vivares CP (1998) Microsporidia, amitochondriate protists, possess a $70-\mathrm{kDa}$ heat shock protein gene of mitochondrial evolutionary origin. Mol Biol Evol 15:683-689

Pichot Y, Comps M, Tigé G, Grizel H, Rabouin MA (1979) Recherches sur Bonamia ostreae gen. n., sp. n., parasite

Editorial responsibility: Albert Sparks,

Seattle, Washington, USA nouveau de l'huître plate Ostrea edulis. Rev Trav Inst Pêches Mar 43:131-140

Pimenta PF, Touray M, Miller L (1994) The journey of malaria sporozoites in the mosquito salivary gland. J Eukaryot Microbiol 41:608-624

Quayle DB (1961) Denman Island oyster disease and mortality, 1960. Fish Res Board Can (Ms Rep Ser) 713:1-9

Roger AJ, Morrison HG, Sogin ML (1999) Primary structure and phylogenetic relationships of a malate dehydrogenase gene from Giardia lamblia. J Mol Evol 48:750-755

Scheer U, Hock R (1999) Structure and function of the nucleolus. Curr Opin Cell Biol 11:385-390

Shapiro SZ, Webster P (1989) Coated vesicles from the protozoan parasite Trypanosoma brucei: purification and characterization. J Protozool 36:344-349

Silverman DJ (1984) Rickettsia rickettsii-induced cellular injury of human vascular endothelium in vitro. Infect Immun 44:545-553

Sinai AP, Joiner KA (1997) Safe haven: the cell biology of nonfusogenic pathogen vacuoles. Annu Rev Microbiol 51: 415-462

Sinai AP, Webster P, Joiner KA (1997) Association of host cell endoplasmic reticulum and mitochondria with the Toxoplasma gondii parasitophorous vacuole membrane: a high affinity interaction. J Cell Sci 110:2117-2128

Sorenson SW, Billington CJ, Norris SA, Briggs JE, Reding MT, Filice GA (1997) Toxoplasma gondii: metabolism of intracellular tachyzoites is affected by host cell ATP production. Exp Parasitol 85:101-104

Van der Giezen M, Sjollema KA, Artz RR, Alkema W, Prins RA (1997) Hydrogenosomes in the anaerobic fungus Neocallimastix frontalis have a double membrane but lack associated organelle genome. FEBS Lett 408:147-150

Submitted: February 14, 2001; Accepted: April 10, 2001

Proofs received from author(s): June 26, 2001 